the aforementioned results appear to reveal an aspect of particulate 5-HT and acetylcholine in the brain somewhat different from those supposed hitherto.

\section{AkIra Inouye}

Kryoshi KataOKa

JUNKo SHINAGAWA

Department of Physiology,

Kyoto University,

Kyoto, Japan.

'Inouye, A., Kataoka, K., and Shinagawa, J., Nature, 194, 286 (1962).

'Hunphry, J. H., and Toh, C. C., J. Physiol., 123, 300 (1954).

'Hardisty, R. M., and Stacey, R. S., J. Physiol., 130, 711 (1955).

- Kataoka, K., Jap. J. Physiol., 12, 81 (1962).

s Palladin, A. V., Regional Neurochemistry, 8 (Pergamon Press, 1961).

- Vane, V. R., Brit. J. Pharmacol., 12, 344 (1957).

'Amin, A. H., Crawford, T. B. B., and Gaddum, J. H., J. Physiol., 126, 596 (1954).

- Lehninger, A. L., and Neubert, D., Proc. U.S. Nat. Acad. Sci., 47, 1929 (1961).

- Dombro, R. S., Bradham, L. S., Campbell, N. K., and Woolley, D. W., Biochim. Biophys. Acta, 54, 516 (1961).

\section{Metabolic Activity of Oxy tocin in the Puerperium}

More than half a century has elapsed since Sir Henry Dale first described the oxytocic activity of posterior pituitary extracts ${ }^{1}$. Since that time the biological effects of the oxytocic principle have been widely investigated. and well established ${ }^{2}$. Moreover, oxytocin, vasopressin, and their analogues have been characterized chemically and prepared synthetically ${ }^{3}$. Despite almost universal use of posterior pituitary preparations in clinical obstetrics few investigations have been directed toward the metabolic effects of either natural or synthetic oxytocin. Consequently, the preliminary observations presented here are of interest because they show pronounced changes in blood sugar and plasma non-esterified fatty subjects examined were variable in degree, the pattern of changes observed for glucose and NEFA were consistent at each dosage-level. On the other hand, small and somewhat variable changes were observed in plasma phosphorus, but there was a tendency to positive, rather than negative, values in $\Delta \mathrm{P}$ (Table 1$)$. The results obtained were not apparently different for additional patients who had received methyl ergonovine tartrate, $0.2 \mathrm{mgm}$ at $6-\mathrm{h}$ intervals after delivery and prior to experiment. The duration of the metabolic effect has not been assessed beyond the $3-h$ period of observation, but it is of interest that the metabolie responses reported here persist far beyond the transient $15-20 \mathrm{~min}$ period of "biological activity' evidenced by uterine contractility. Of incidental interest was the finding of similar responses in two patients receiving $10 \mathrm{mu} / \mathrm{kg}$ oxytocin on the fourth postpartum day, one having been delivered by Caesarean section and the other vaginally.

Although interpretation of our results remains speculative, certain experimental reports bear consideration. In vitro investigations using the rat epididymal fat pad have shown that oxytocin increases oxidation of glucose while stimulating glyceride synthesis ${ }^{8}$. Oxytocin resembles insulin in that it increases C-1 oxidation preferentially over that of C-6 (ref. 9). Our failure, however, to find significant decrements in plasma inorganic phosphorus seems inconsistent with increased peripheral glucose utilization. On the other hand, in experimental animals hepatic glucose release has been shown to be unaffected by oxytocin $^{10}$, a finding that fails to support a concept of a central rather than peripheral action in explanation of the hypoglycæmia seen in our data. The precise mechanisms resulting in increased NEFA in association with hypoglycæmia thus are uncertain and the apparently contradictory reports of hyperglycæmia after oxytocin administration in $\operatorname{dogs}^{11}$ and rabbits ${ }^{12}$ may represent species differences in response to this compound. It is also

Table 1. Mean Chafges from Pre-Test Levels for Grodps of 5 Puerperal Women at Each Oxytocin Dosage-Letet. Blood Glucose and Inorganio PHOSPHORUS VALUES ARE IN MG PER OENT. PIASMA NEFA VALUES ARE EXPRESSED AS $\mu$ EQUUV./L.

\begin{tabular}{|c|c|c|c|c|c|c|c|c|c|c|c|c|}
\hline $\begin{array}{l}\text { Oxytocin } \\
(\mathrm{mr} / \mathrm{kg})\end{array}$ & $\Delta$ Glucose & $\begin{array}{c}0.5 \mathrm{~h} \\
\Delta \mathrm{P} \\
\end{array}$ & $\triangle \mathrm{NEFA}$ & $\Delta$ Glucose & $\begin{array}{l}1 \mathrm{~h} \\
\Delta \mathbf{P}\end{array}$ & $\triangle \mathrm{NEFA}$ & $\Delta$ Glucose & $\begin{array}{r}2 \mathrm{~h} \\
\Delta \mathrm{P} \\
\end{array}$ & $\triangle N E F A$ & $\Delta$ Glucose & $\begin{array}{l}3 \mathrm{~h} \\
\Delta \mathrm{P} \\
\end{array}$ & $\triangle N E F A$ \\
\hline $\begin{array}{r}10 \\
100 \\
400\end{array}$ & $\begin{array}{l}-8 \\
+10 \\
+0.4\end{array}$ & $\begin{array}{l}+0.05 \\
+0.39 \\
+0.03\end{array}$ & $\begin{array}{l}+119 \\
+105 \\
+132\end{array}$ & $\begin{array}{r}-11 \\
+8 \\
-6\end{array}$ & $\begin{array}{l}+0.08 \\
+0.08 \\
+0.07\end{array}$ & $\begin{array}{l}+223 \\
+293 \\
+288\end{array}$ & $\begin{array}{l}-29 \\
-18 \\
-21\end{array}$ & $\begin{array}{l}+0.20 \\
+0.05 \\
+0.11\end{array}$ & $\begin{array}{l}+453 \\
+551 \\
+494\end{array}$ & $\begin{array}{l}-36 \\
-25 \\
-48\end{array}$ & $\begin{array}{l}+0.28 \\
+0.03 \\
+0.07\end{array}$ & $\begin{array}{l}+542 \\
+620 \\
+597\end{array}$ \\
\hline
\end{tabular}

acids after administration of oxytocin to puerperal women.

In the present experiments clinically normal patients were studied within $36 \mathrm{~h}$ following uncomplicated vaginal delivery. Synthetic oxytocin ('Syntocinon' kindly supplied by Dr. R. Bircher, medical director, Sandoz Pharmaceuticals, Hanover, New Jersey) in $10 \mathrm{ml}$. physiological saline solution was administered rapidly by vein at dosage-levels between $10 \mathrm{mu}$ and $400 \mathrm{mu}$ per $\mathrm{kg}$ body weight. In addition to a pre-test blood specimen, venous blood samples were obtained at $0.5 \mathrm{~h}$ intervals for $3 \mathrm{~h}$ after treatment with oxytocin. Blood sugar was estimated by the Somogyi-Nelson technique $e^{4,5}$, plasma inorganic phosphorus by the method of Fiske and Subbarow ${ }^{6}$, and plasma non-esterified fatty acids were extracted and titrated by the method described by Dole? . The results are expressed as increments or decrements from pre-test levels of glucose $(\Delta G)$, phosphorus $(\Delta P)$, and non-esterified fatty acids ( $\triangle$ NEFA). Representative data for three groups of five patients each at the $0.5,1,2$, and $3 \mathrm{~h}$ intervals are shown in Table 1.

Attention is directed to the unexpected finding of an inverse effect of oxytocin on blood sugar and NEFA, the former decreasing after a lag period of $1-1.5 \mathrm{~h}$ while the latter showed a prompt and large increase. (In separate control studies NEFA glucose and phosphorus remained quite constant during the $3-\mathrm{h}$ observation period.) Although the quantitative responses observed for the 15 possible that as yet poorly understood metabolic influences of the early puerperium may result in the divergent responses of blood glucose and plasma non-esterified fatty acids that we have observed.

This work was supported by U.S. Public Health Service grant $A-4180$.

Richard L. BURT

Norman H. Leake

Warren $N$. Dannenburg

Department of Obstetrics and Gynecology,

Bowman Gray School of Medicine,

Winston-Salem,

North Carolina.

1 Dale, H. H., J. Physiol., 34, 163 (1906).

${ }^{2}$ Caldeyro-Barcia, R., and Heller, H., Oxytocin (Pergamon Press, New York, 1961). ${ }^{3}$ Boissonas, R. A., Guttman, S., Berde, B., and Konzett, H., Experientia,

4 Somogyi, M., J. Biol. Chem., 86, 655 (1930).

${ }^{5}$ Nelson, N., J. Biol. Chem., 153, 375 (1944).

- Fiske, C. H., and Subbarow, Y., J. Biol. Chem., 66, 375 (1925).

'Dole, V. P., J. Clin. Invest., 35, 150 (1956).

${ }^{8}$ Mirsky, I. A., and Perisutti, G., Biochim. Biophys. Acta, 50, 603 (1961).

- Pittman, J. A., Boshell, B. R., Williams, B. H., Hamner, D., and Hill, P., Biochem. and Biophys. Res. Comm., 6, 29 (1961).

${ }^{10}$ Bergen, S. S., Sullivan, R. Hilton, J. G., Willis, S. W., and Van Italie,
T. B., Amer. J. Physiol., 199, 136 (1960).

A., Proc. Soc. Exp. Biol. and Med., 110, 42 (1962).

audhury, R. R., and Nayyar, P. P., Toxicol. and Applied Pharmacol., 